\title{
ARCHITECTURE TRADITIONAL MAKASSAR WITH THE IDEAL FORM BASED TO RESIDENTIAL ENVIRONMENT HUMANISTIC (CASE: SETTLEMENT PROCESSING BRICKS GOWA IN SOUTH SULAWESI)
}

\author{
Imriyanti $^{1^{*}}$, Shirly Wunas ${ }^{2}$, Mimi Arifin ${ }^{2}$ \\ ${ }^{1}$ Graduate Student, Departement of Architecture, Faculty of Engineering Hasanuddin University \\ ${ }^{2}$ Lecture Departement of Architecture, Faculty of Engineering Hasanuddin University \\ *Corresponding author; Email: imrianti@gmail.com
}

\begin{abstract}
The traditional architecture is the cultural identity of a tribe because they have life of its people. Traditional architecture experiencing growth and renewal. Renewal of the traditional architecture of Makassar happens usually get influences from the outside architecture that fit into the traditional architecture thus experiencing blend elements of culture, but the culture of the traditional architecture of original tribes of Makassar maintain, this is called acculturation. Acculturation is a blend of one cultural and the other retaining local indigenous culture. The traditional architecture is experiencing a mix of cultures occurs in public housing environment is an element of the macro, mezo and micro. Incessant development in various sectors particularly the sectors of housing and settlement, this is what happen in the settlement processing brick Gowa district, where the development of the construction of the society processor brick has provoked aspects psychology, than it is that it raises the problem is how the role of ideal form of architecture Makassar who have undergone traditional blend of cultures can form needs humanist residential environment that is safe, convenient, and economic, hygienic. The purpose of this study was to analyze element the of original culture at traditional Makassar particularly in ideal form home to work place primary and support in shaping the residential environment humanist. This research is a descriptive exploratory and interpretative studied theoretically by means observe directly the ideal form of settlement processing bricks in Gowa of South Sulawesi. The results of this study indicate the ideal form of settlement processing in the hamlet brick- Giring-Giring Village Kalase'rena Bontonompo Gowa District of review the system orientation of the house, the tread pattern of at macro space occupancy humanist element appear in the system path, distance, direction of the wind, the working group, the increase in the economic, social and hierarchy family indicates comfort, security, economic to the location of key livelihood source and support to the community house brick processing.
\end{abstract}

Keywords: Traditional architecture Makassar; acculturation; ideal form; settlement brick; humanist.

\section{INTRODUCTION}

The traditional architecture is the cultural identity of a tribe because they have life of its people. Traditional architecture experiencing growth and renewal. Renewal process is what causes a shift in the culture of Indonesia forms one of the traditional architecture culture form Makassar is the ideal form (Mardanas, 1995). Renewal of the traditional architecture of Makassar happens usually get influences from the outside architecture that fit into the traditional architecture thus experiencing blend elements of culture, but the culture at traditional architecture the original tribes of Makassar maintained, this is called acculturation. Acculturation is a blend of one cultural and the other retaining local indigenous culture. In general acculturation concluded as a social process that occurs when a group of people with a particular culture are confronted with elements of a foreign culture in such a way, so that the elements of foreign culture was gradually accepted and processed into their own culture without causing the loss of personality culture at self (Pratiwi. H.P. 2010). Makassar tribal culture that blends with the exterior architecture is an element of the macro, mezo and micro, but in the newness of it very quickly changes are the macro elements at settlements. Macro elements related to the ideal form a settlements, can be judged from the orientation of the house, tread and the pattern of settlements macro space.

Residential or residential neighborhood is a residential area which has the facilities and infrastructure, public utilities, as well as having to support activities of other functions in urban and rural areas (Undang-Undang No. 1 Tahun 2011) about housing and residential areas. Shelter/humanist settlement is closely related to human and architecture, among others: 1) Basic human needs (human needs), 2). Human needs as a community (society), 3) human needs in environmental, economic globalization and, 4) the role of humans as a protector of nature and create a sustainable quality of life (Rachmawati, 2009). Occupancy humanist is one of a very influential with nature in the form of comfort, safe, and economic on space hygienic macro and micro space of a house (Wunas, 2011). Having regard to the above it is traditional architecture, especially the traditional Makassar tribe has experienced a fusion with elements of other cultures due to the incessant 
development in various sectors particularly the sectors of housing and settlements, this is what happened in the settlement processing brick Gowa district, where the development of the development of the society processing of bricks has lead psychology aspect, from that that it causes problems, namely how the role of Makassar ideal form of traditional architecture which has undergone a fusion of cultures can shape the environment needs residential humanist safe, convenient, and economic hygienic. The purpose of this study was to analyze the elements of the original culture of traditional Makassar particularly in ideal form home to work place primary and support in shaping the residential environment humanist.

\section{THEORETICAL APPROACH}

\section{Acculturation}

Overview of the concept of acculturation (Prawati, 2010) that acculturation as social process that occurs when a group of people with a particular culture are confronted with elements of a foreign culture in such a way, so that the elements of foreign culture was gradually accepted and process into their own culture without losing the personality of that culture own. In this case there is a difference between the culture is difficult to change and are affected by elements of foreign culture (covert culture), with the cultural wing of the volatile and influence by elements of foreign culture (overt culture). Covert culture for example: 1) The system of cultural values, 2) religious belief are considered sacred, 3) Some customs that have been learned very early in the socialization process of individual, and 4) Some customs that have netted comprehensive functionality in society.

While overt culture for example: physical culture, such as tools and objects that are useful, but also science, ordinances, lifestyle, and recreation are useful and provide comfort. In some explanation of the science of sociology, the acculturation process can be described as follows:

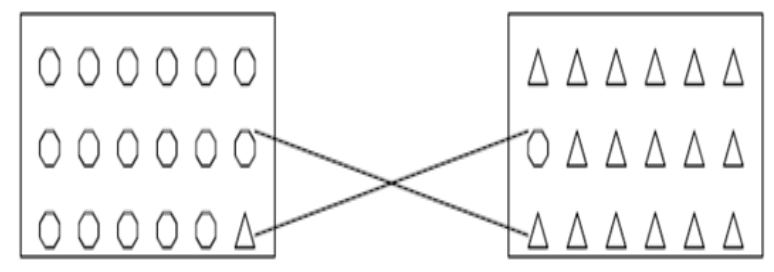

Fig. 1. The Elements of the Culture of Each of the Different Cultures Intermingled with one Another as a Result of Association or Intensive Interaction in a Long Time, but did not lead to the emergence of a new culture. (Prawati 2010).

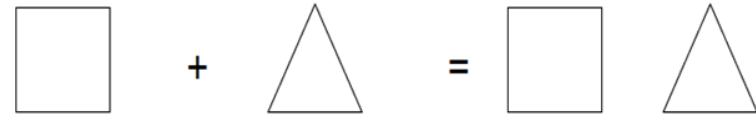

Fig. 2. Two Different Cultures to Form a New Culture does not Eliminate the Characteristics of Each Culture. (Prawati, 2010).

Theory J. Powel in Koentjaraningrat (1982), that acculturation can be interpreted as the entry of foreign cultural values into traditional local culture. The different cultures that meet, that outside influences have been able to reach an equilibrium. Koentjaraningrat define acculturation as a culture in the community who are affected by a foreign culture that is so different in nature, so that the elements of foreign culture gradually accommodated and integrated into their own culture without losing the personality and culture. Acculturation among tribes are related, but different cultures is usually one of the people associated it occupy a dominant position. At first the term used in relations between nations east and west. East population attended Western culture eventually declared himself traces the relationship in terms of life, for example in clothing, housing, education, social, economic, arts and others.

\section{Architecture Traditional}

Architecture is a statement of space and time of the entire life of a civilized society, which provide a forum for all activities community life. Then to community activities require a container of space. The daily activities of a civilized society diverse, all of which need a room or a place to perform these activities. Suprijanto (2000) revealed that traditional is a tradition, something (the rules, requirements, guidelines) that is inherited, that is where the process of forwarding rules or the rules of tradition adapted to the circumstances or the times, so that when changes are inherently essentials.

Traditional architecture became one of the cultural elements that grow and develop along with the growth of a tribe or nation. In traditional architecture ideal embodied in an integrated form, a form of social and material form a regional culture (Mardanas, 1985). Context cultured in traditional architecture can be seen from the aspect of physical and non-physical aspects. The physical aspect is precisely the priority list is the final, while the nonphysical aspects top priority as the process of formation of the home, based on the rituals of religion or belief, who prefer the validity of the real world and the higher realms (Tjahyono in Suprijanto, 2000).

According to Frick (2007), the traditional home as a work of architecture is not just a material composition and structure of the building located on a 
site / location but rather a manifestation ritual aspects, cultural, social, material, engineering, craftsmanship and trade. In fact, according Haryadi and Setiawan (1995) factors of religion and belief is considered very influential on the shape and pattern of the house even in traditional societies tend to be the dominant factor than other factors.

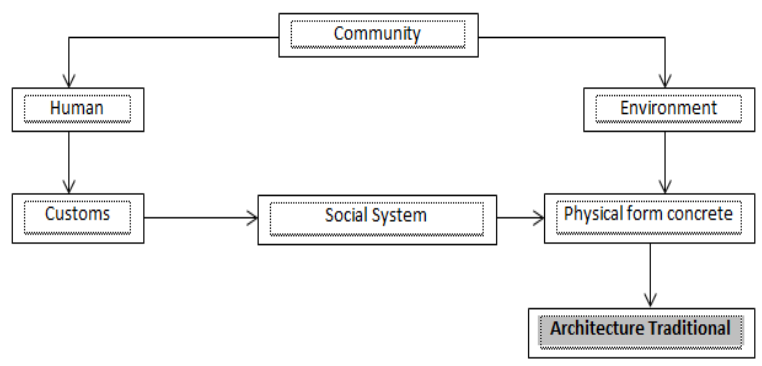

Fig. 3. Scheme Understanding of Architecture Traditional (Koentjaraningrat, 1993)

Traditional house is a cultural manifestation (Culture), the cultural values will be expressed and applied in the art of architecture. Architecture is a manifestation of cultural values, both cultural values of individuals and cultural values of communities (Christian, 2006).

\section{The Being Ideal}

Ideal form is part of the culture form. Have in common with the ideal form of ideology, where ideology is a collection of ideas that derived systematically in a form. According to Destutt de Tracy, ideology can be regarded as a comprehensive vision as a way of looking at things in general in everyday life and some of the philosophical direction (1796). Values indicated ideological culture through cultural phenomenon. According to J.J. Honingmann there are three cultural phenomenon, namely ideas, activities and artifacts (in Koentjaraningrat, 2005; 74). Koentjaraningrat offers four culture form, namely: culture as an ideological value; culture as a system of ideas; culture as a system of behavior and actions are patterned; culture as a physical object (artifacts) (Koentjaraningrat, 2005).

\section{Settlement Produce Bricks}

The settlements are part of the environment outside the protected area, either in the form of urban and rural area that serves as a living environment or residential environment and the activities that support the livelihoods and livelihood (SNI 03-6967-2003). Settlement as a place (space) to live and livers for human groups (Doxiadis 1968). According Doxiadis, settlements (Human Settlement) will go well if associated with several elements, namely: Nature
(Nature), Man (Human), Society (social life), Shell (building / house or room), and Networks. Settlement producer of bricks is a residential area where people pursue the activity / activities as brick makers. The area is scattered in various regions in Indonesia, brickproducing region is supported by the environmental conditions that have a brick-making material is clay.

\section{METHODS}

This research is a descriptive exploratory and interpretative studied theoretically by means observe directly the ideal form of settlement processing bricks in Gowa of South Sulawesi. Data collection methods used are literature research (Library Research), research Field (Field Research) such as observation, interviews and field notes. The study population was at the house of the main and supporting workplace, distance from the house, toward the house against the wind, kinship system processor brick in Gowa of South Sulawesi. Determination of the number to the sampling for a descriptive study least $10 \%$ of the population (Sugiyono. 2008). The mechanism of sampling is to determine / identify the number of each category, in which each existing category then sample was determined at random. (Moleong 1996). Analysis of the data on the ideal form residential/home processing bricks in Gowa which identify the orientation of the house (activities into the workplace, road and winds), the tread pattern of the house (home production, distance and working groups), the pattern of macro (hierarchy social, economic and family).

\section{RESULTS AND DISCUSSION}

\section{Location Research}

This study is in Gowa Administratively, Gowa regency is at the bottom of the island of Sulawesi. Gowa is located on West Longitude 119.37730 and 120.03170 East longitude and latitude 5.0829342 8620 North and South Latitude 5.5773054370; where territory is situated in the southern part of South Sulawesi province with an area of 1883.33 square kilometers, equivalent to $3.01 \%$ of the area of South Sulawesi.

Location pengelolahan bricks located in the hamlet village Giring-Giring-Bontonompo Kalase' rena District of Gowa. The hamlet Giring-Giring located at an altitude above sea level to $22.00 \%$ with an area of $2.34 \mathrm{~km} 2$. Distance from Hamlet-Leads Leads to the district capital of $\pm 1 \mathrm{~km}$ and the distance to the district headquarters $\pm 21 \mathrm{~km}$. Settlement processing in Hamlet brick-Giring-Giring Village Kalase'rena Bontonompo District of Gowa a high percentage of $\pm 0.07 \%$ with a population of 381 people. The hamlet Giring-Giring has a tropical climate with conditions of fields and gardens of rain- 


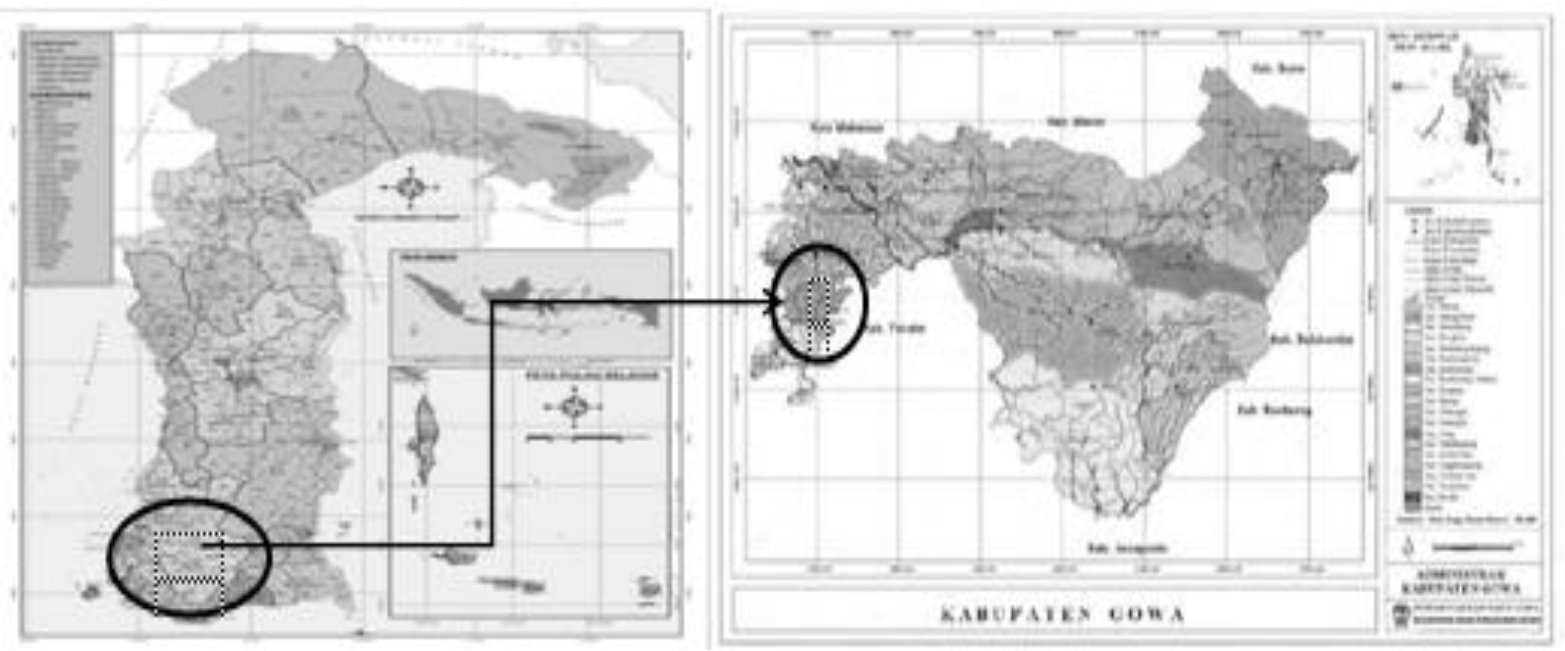

Fig. 4. Map of the Territory of South Sulawesi Province and Map Gowa. (Source: Study LP2B Gowa Regency, South Sulawesi, 2016).

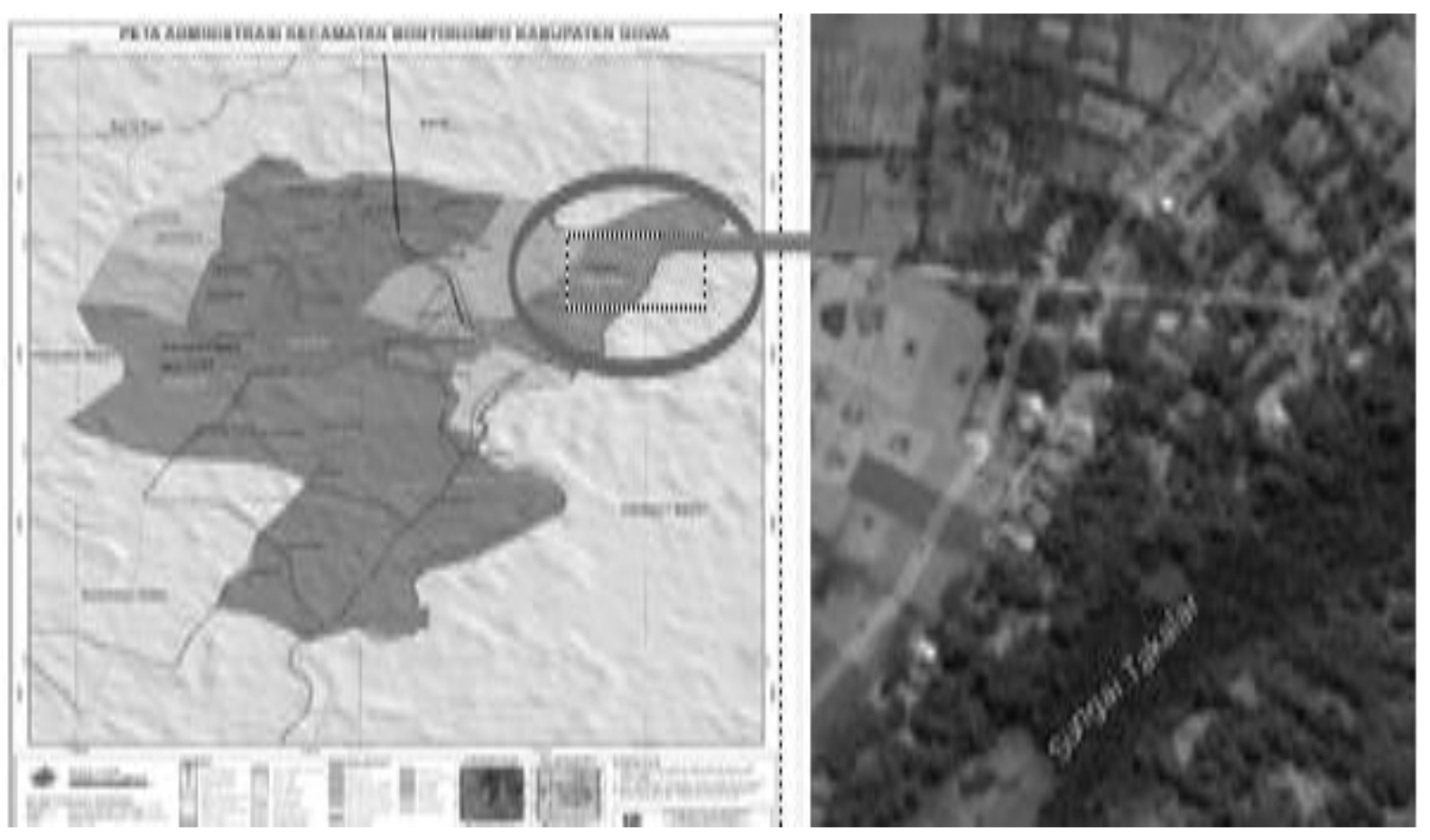

Fig. 5. Map of the Hamlet Administration Giring-Giring Kalaserena village Bontonompo District Gowa Regency (Source: Google Earth, 2015).

fed, so that people are known by the rain-dependent farmers, because during the rainy season rice farming as the main livelihood will be done so that during the dry season people make bricks as a livelihood support. But with livelihood support the economic level of the people is increasing.

\section{Orientation House}

Occupancy in hamlet village Giring-Giring Kalase'rena Bontonompo district of Gowa district is residential with traditional architectural forms, namely Makassar houses on stilts, but most houses have undergone changes and development. The development occurs on the form, structure and material dwelling.

Settlement pattern in Hamlet Giring-GiringBontonompo village Kalase'rena district of Gowa shaped pattern is split so that the pattern arrangement of the settlement were not exposed but the location of the home communities rather far apart. 


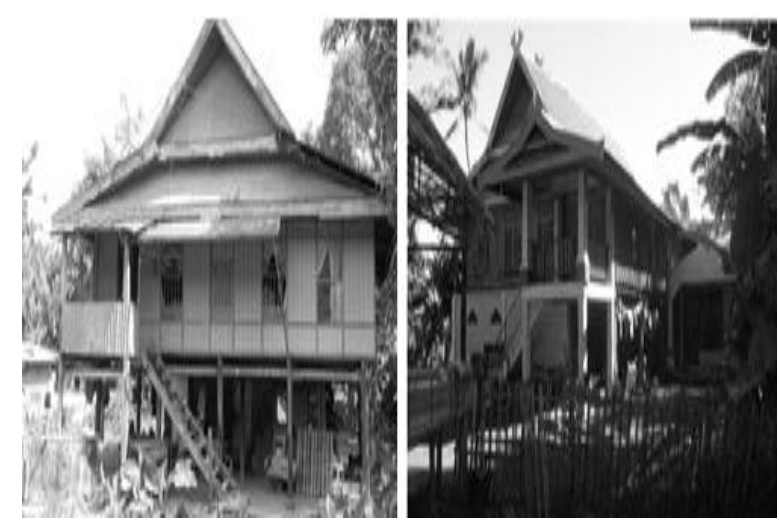

Fig. 6. Shape Occupancy in Hamlet Village Giring-Giring Kalase'rena. (Source: The results of the survey, 2016)

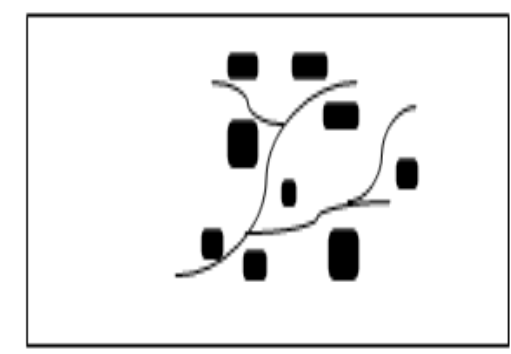

Fig. 7. The Pattern of the Scattered Settlements. (Source: Bintarto, 1983 in Daljoeni N, 2014)

Settlement pattern that spreads directed by demonstrating the limits sensitivity to space and territory are still intimate for man, the network structure of village road by lines of circulation formed within a scope of traditional village, which led to the restriction of land / ground in order to reach by activity human. The road is a particular way of dealing with the spatial space. road in the traditional village into a physical object that is the main point once a transitional space (Habraken, 1983).

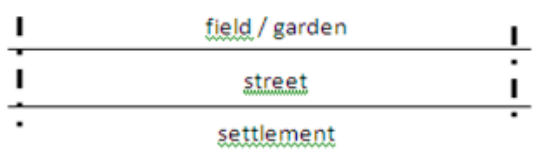

Fig. 8. Orientation the House from to street Pattern and the main work in the hamlet-Giring-Giring Kalase'rena Village district. Bontonompo Kab. Gowa. (Source: The results of the survey, 2016)

For orientation occupancy in the village associated with the direction of the wind, because each cardinal direction has meaning for the people of hamlet Giring-Giring that a tribe Makassar. Makassar tribe is one of the largest tribes in the province of South Sulawesi, which has requirements and rules of living, so people tend to follow the terms and the rule because it is a symbol of the living (Idawarni, 2011).

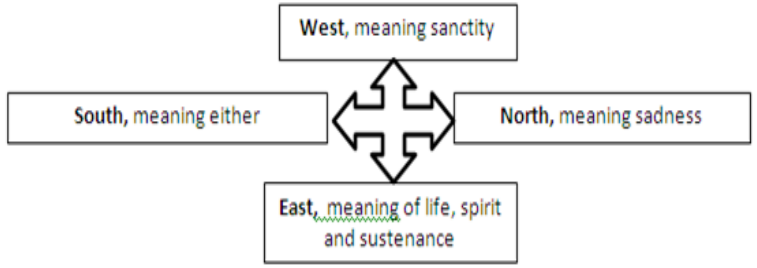

Fig. 9. Meaning Direction of the Wind is believed HamletGiring-Giring. (Source: The results of the survey, 2016)

By paying attention to the wind direction, the direction of orientation of the houses in the hamlet Giring-Giring always leads south and east as well as the orientation of the processing of the bricks in the village. When connected to a residential patterns and wind direction came the wind direction from west to east while processing a brick placed in the south so that the dust and the wind from the direction of processing the brick does not lead directly towards occupancy. This is in accordance with one characteristic of the humanist occupancy is hygienic.

The orientation of the home to the workplace and the system winds assessed humanist so close that the outreach system is economic, convenient and secure because:

1. Residential close to the workplace so as to reach on foot.

2. The pattern of occupancy of the road directly facing the street that serves as a barrier to the workplace.

3. Directions eye angina located in a residential community bricks dominant processor Makassar tribes are very confident with the direction of the wind that has meaning, namely: west meaningful sanctity, north meaningful sadness, east meaningful life, spirit, sustenance and south meaningful for both.

\section{Tread Pattern Home}

The tread pattern processing brick house in the hamlet Giring-Giring follow-lane road but brickyard located in neighborhoods around the community both in the back and side of his house. The process of making bricks in Hamlet Giring-Giring done individually that each family has to combustion Bantilan but there are several families join each other in the combustion process, it is usually done when the relationship of family is very close.

Distance brickyard \pm 50 meters away from their house. There is also a brick kiln located on the side, rear and front of the houses, this is done because processing the bricks do every day when there is spare time / leisure, so the placement distance is not far from their house. When viewed in terms of 
occupancy humanist then it can be considered humanist because in terms of form and material brickyard is not permanent and the distance from people's homes is not much can be category as very economical for the people processing the bricks.

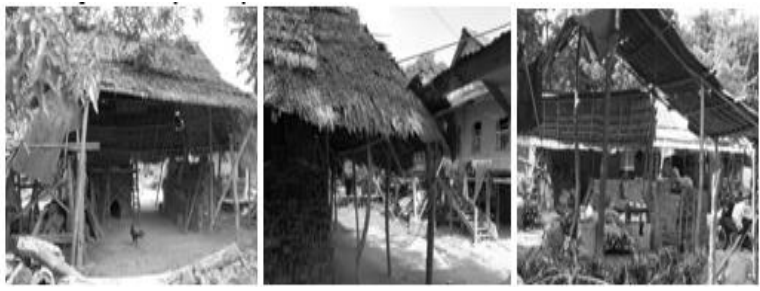

Fig. 10. "Bantilan" a Brick in the Hamlet Processing Giring-Giring (Source: The results of the survey, 2016).

\section{Patterns Space Macro}

In terms of the spatial pattern macro processors brick house in Hamlet-Giring-Giring Kalase'rena village is closely connected with the main livelihood and supporting so interconnected social hierarchy.
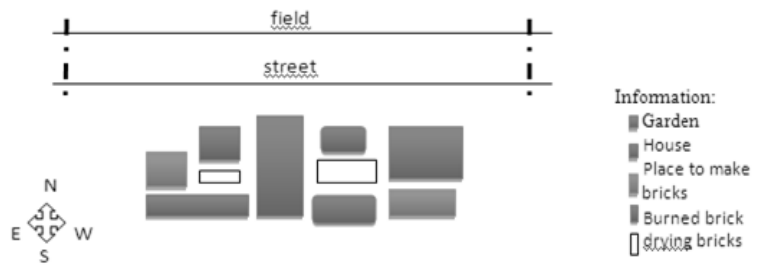

Fig. 11. Pattern Space Macro Occupancy with main and supporting work in the Hamlet-Giring-Giring. (Source: The results of the survey, 2016).

Pattern macro space occupancy direction of the road in the hamlet village Giring-Giring always side by side with the garden and making bricks while brick kiln in place on the back of the house, so that the space program's main and supporting workplace has been organized in accordance with spatial space between the housing and the workplace. GiringGiring in Hamlet there is also a pattern of work at brick kilns in group are based on the kinship / family.

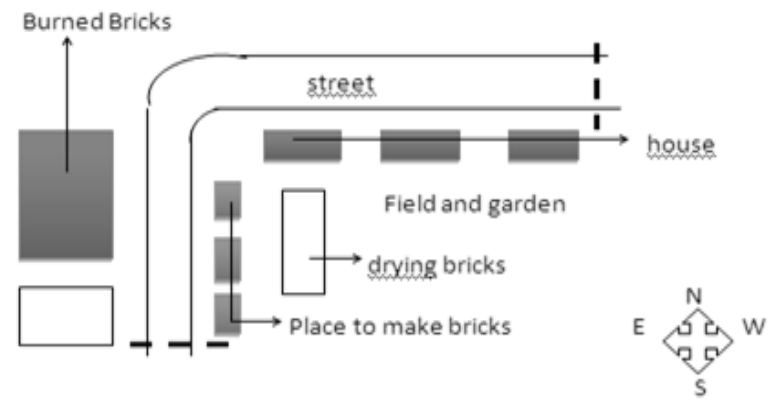

Fig. 12. Pattern Space. Macro Dwelling and Place of Manufacture and Burning Rocks in Groups. (Source: The results of the survey, 2016)
The community processors brick tend to have / the same degree of the offspring "Tau Maradeka", but with their livelihood support as a processor, a brick, the economic level of society increases and the results of the management of bricks higher income compared with agriculture as the main livelihood. The supporting livelihoods through that as a processor, then the form of a brick dwelling has undergone a change from the traditional to the modern, namely on the form of a stage becomes stage. Development and change the shape of the area under the house into the area of public, private and service. Development and changes can also be influenced by the growing number of residents of the house that is the family who opted to stay which eventually became known by the system Uxirilokal that the growing number of residents of the house for girls homeowners have married and her husband opted to stay at home that while her son who has been married by to the woman's family / wife and that the rules in Makassar tribal kinship system.

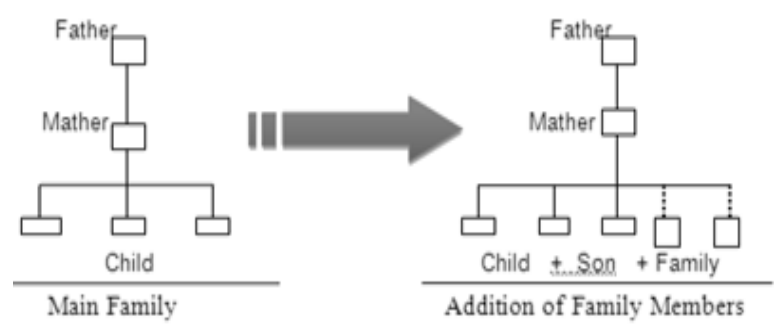

Fig. 13. Structure of Families with Tribal Uxorilokal system Makassar.

The existence of law and family in one household greatly influence the amount and function of traditional homes that tend to be homeowners who are in Hamlet Giring-Giring development home to siring/foot house that finally gives special characteristics of appearance and shape of the house. With the bottom of the hierarchy of social, economic and family is very influential on the spatial patterns of macro and provide comfort to the humanist community residential brick processing.

\section{CONCLUSION}

The Community processors in Hamlet brickGiring-Giring Kalase'rena village of ideal form that analyzes system orientation of the house, the tread pattern and the pattern of macro space occupancy which has a settlement patterns are dispersed, then:

1. People are more familiar with the system orientation of the dwelling in terms of the direction of the wind that has significance for the tribe Makassar namely the north meaningful sadness, 
south meaningful for both, east meaningful life, spirit, sustenance and westward meaningful purity. The meaning of the brick dwelling dominant processor to the south and the east, so the place worked well in terms of main and supporting work very close at the same time dealing with occupancy. Rice fields and the processing of bricks tend toward the east and south which gives a sense of comfort and security for people in the hamlet processing brick-Giring-Giring village.

2. The tread pattern processing house brick distances between the main source of livelihood and support is very close to the shelter so it can be reached by foot which gives economic value to society.

3. From the spatial pattern macro processors brick house known field/garden and place of manufacture and brick kilns located in a residential neighborhood communities, so the main job and support can be monitored from its occupancy. Improved economy of the people grow with the changes and development of the stilts house becomes the stage and it is influenced by the increasing number of residents who are connected to the system development Makassar tribal family structure that embraces Uxirilokal system. When viewed as a humane settlement processing in the hamlet brick-Giring-Giring Kalase'rena village is very safe, economic and convenient.

\section{REFERENCES}

Daldjoeni, N. (2014). Geography Town and Village. Publisher Ombak, Yogyakarta

Habraken, N.J. (1983). Transformation of The Site. Camridge, Massachusetts: A Water Press.

Idawarni (2011). Determination Directions and Location of Residential And House Live Relation With Cosmology (Case Study, Kampung Kanarea, District Bajeng Gowa in South Sulawesi) Local Wisdom-Jurnal Ilmiah Online, Issn: 20863764. P 09-18

Koentjaraningrat (2005). Introduction to Anthropology, Rineka Cipta, Jakarta

Mardanas, I. et. al. (1985). Traditional Architecture of South Sulawesi, Dep. P and K, Jakarta.

Moleong (1996). Qualitative Research Methodology, Rosdakarya, Bandung.

Prawati, H. P. (2010). Assimilation and Acculturation: A Review of the Draft.

Rachmawati, M. (2009). Humanism Back in Architecture. NALARs Journal, 9(2) pp.103-116.

Sugiyono (2008). Understanding Qualitative Research. Alphabeta, Bandung.

Study LP2B District Gowa, South Sulawesi, 2014

Undang-Undang No. 1 Tahun 2011, On Housing and Settlement area. Ministry of Housing. Jakarta.

Wunas, S. (2011). City of Humanist. Brilliant International, Surabaya. 